\title{
First discovery of Plasmobatidae (Acari, Oribatida) in Gabon, redefinition and new species of the genus Solenozetes Grandjean, 1932
}

\author{
Nestor FERNANDEZ \\ National Council of Scientific and Technological Research. \\ La Rioja University Campus. Research and Technology City. \\ Av. Luis Mansueto de la Fuente $\mathrm{S} / \mathrm{N}$, \\ (5300) La Rioja (Argentina) \\ nestorfernand51@yahoo.fr \\ Pieter THERON \\ Research Unit for Environmental Sciences and Management, \\ North-West University, \\ Potchefstroom Campus, 2520 (South Africa) \\ pieter.theron@nwu.ac.za \\ Christine ROLLARD \\ Muséum national d'Histoire naturelle, \\ Département Systématique et Évolution, UMR 7205, CNRS, \\ Case postale 53, 57 rue Cuvier, F-75231 Paris cedex 05 (France) \\ chroll@mnhn.fr
}

KEY WORDS Acari, Oribatida, Plasmobatidae, Solenozetes makokouensi n. sp.; Solenozetes redefined,
Fernandez N., Theron P. \& Rollard C. 2013. - First discovery of Plasmobatidae (Acari, Oribatida) in Gabon, redefinition and new species of the genus Solenozetes Grandjean, 1932. Zoosystema 35 (2): 137-150. http://dx.doi.org/10.5252/z2013n2a1

\section{ABSTRACT}

The family Plasmobatidae is herewith reported for the first time from Gabon and Solenozetes makokouensis n. sp. is described. The holotype was collected from litter in dense evergreen humid forest, Makokou, Province Ogoové-Ivindo, north-eastern Gabon. The species is described and illustrated based on adult females. The new species is easily distinguishable by the following combination of character states: cerotegumental layer amorphous, with small tuberculations mixed with granulations; $r$ seta falcate, inserted on forward-extending visorlike protuberance; in seta wrapped in cerotegumental granulate layer; prodorsal anterior zone complex with irregular protuberances; bothridium horseshoe-shaped, internal rings appearing gear-like; sensillus filiform; notogaster anteriorly with semicircular furrow and depressed zone; macropores opening on foveae; notogastral microsculpture irregular foveate pattern; opisthosomal gland apophysis conical with rounded tip; five pairs of notogastral setae. The genus Solenozetes is redefined. 


\author{
MOTS CLÉS \\ Acari, \\ Oribatida, \\ Plasmobatidae, \\ Solenozetes makokouensis \\ n. sp., \\ redéfinition de \\ Solenozetes, \\ Gabon
}

\begin{abstract}
RÉSUMÉ
Première découverte des Plasmobatidae (Acari, Oribatida) au Gabon, redéfinition et nouvelle espèce du genre Solenozetes Grandjean, 1932.

La famille Plasmobatidae a été trouvée pour la première fois au Gabon. Une espèce nouvelle Solenozetes makokuensis n. sp., est décrite et illustrée, sur la base de la stase adulte femelle. Le matériel-type a été récolté à Makokou, dans la Province Ogoové-Ivindo au nord-est du Gabon. La nouvelle espèce est caractérisée par : une couche cérotégumentaire amorphe, comprenant des petites tubercules mélangées à des granulations; le poil ro gonflé, situé sur une protubérance avec une expansion basale en visière ; le poil in, immergé dans une couche de cérotégument granulée; la zone prodorsale antérieure complexe avec des protubérances irrégulières; le bothridium en forme de fer à cheval, avec des anneaux intérieurs semblables à des engrenages; le sensillus filiforme ; la zone antérieure du notogaster déprimée avec un sillon semi-circulaire ; les macropores situés dans des concavités ; la microsculpture du notogaster, constitué par des petites concavités à bord franc de taille variable; l'apophyse de la glande latéro-abdominale conique à pointe arrondie ; cinq paires de poils gastronotiques. Le genre Solenozetes est redéfini.
\end{abstract}

\section{INTRODUCTION}

Makokou is located in the Ogoové-Ivindo Province in north-eastern Gabon, slightly north of the equator at 500 metres asl. Tropical climate, with annual rainfall of $1700 \mathrm{~mm}$, average temperature $24^{\circ} \mathrm{C}$. (UNESCO 1987).

During the last four years, we have studied a very large collection of oribatid mites from Gabon (collection Y. Coineau), deposited in the Muséum national d'Histoire naturelle, Paris, France.

This is the first report on the fauna collected at the Makokou Research Station, Gabon. The Plasmobatidae have never before been reported from Gabon (Subias 2004 actualized 2011).

The family Plasmobatidae was established by Grandjean (1961a) with three genera viz. Plasmobates Grandjean , 1939 with Plasmobates pagoda Grandjean, 1929 as type species; Solenozetes Grandjean, 1932 with S. cribratus (Grandjean, 1929) as type species and Orbiculobates Grandjean, 1961 with O. orbiculus (Grandjean, 1929) as type species. Recently the genus Malgachebates Fernandez, Cleva \& Theron 2011 with $M$. peyrierasi Fernandez, Cleva $\&$ Theron, 2011 was added. At present the family is composed of four genera and twenty one species (Subias 2004; Fernandez et al. 2011).
The diagnostic situation of the genus Solenozetes is complex due to diverse viewpoints, oversights, omissions and errors in previous descriptions. For this reason a decision was made to use only the characteristics of the type species Solenozetes cribratus as described by Grandjean (1929; 1961a) to define the genus in our paper on Malgachebates peyrierasi and await the opportunity to explain our point of view.

The genus Solenozetes contains six species at present (sensu Subias op. cit): S. cribratus, S. australis (Balogh \& Csiszár, 1963), S. carinatus (Hammer, 1961), S. flagellatus Balogh \& Mahunka, 1969, S. flagellifer Mahunka, 1983 and S. gallonae Hunt, 1994.

\section{MATERIAL AND METHODS}

All specimens were collected from decomposing plant debris using standard Berlese-Tullgren funnel extractor.

Specimens studied with light microscopy were preserved in $70 \%$ ethanol, macerated with lactic acid, and observed in the same medium using the open-mount technique (cavity slide and cover slip) described by Grandjean (1949) as well as Krantz and Walter (2009). Line drawings were made using an 
Olympus BHC compound microscope equipped with a drawing tube.

Specimens were studied with the aid of scanning electron microscopy (SEM): specimens preserved in ethanol were carefully washed by sucking them several times into a Pasteur pipette, then transferred for two hours to buffered glutaraldehyde $(2.5 \%)$ in Sörensen phosphate buffer: $\mathrm{pH} 7.4 ; 0.1 \mathrm{~m}$. Following postfixation of two hours in buffered $2 \% \mathrm{OsO}_{4}$ solution they were rinsed in buffer solution; all specimens were then dehydrated in a series of graded ethanols and dried in a critical point drier. After mounting on Al-stubs with double sided sticky tape, specimens were gold coated in a sputter apparatus.

Those specimens from which the cerotegument was to be removed were macerated in warm lactic acid (70 \%) for 7-15 days, after which the cerotegument was carefully removed using fine needles, before being dehydrated in a series of graded ethanols.

The following measurements were taken: total length (tip of rostrum to posterior edge of notogaster); width (widest part of notogaster). All measurements are given in micrometres $(\mu \mathrm{m})$.

Setal formulae of the legs include the number of solenidia (in parentheses); tarsal setal formulae include the famulus $(\varepsilon)$.

\section{ABBREVIATIONS}

\section{MORPHOLOGY}

Morphological terms and abbreviations used herein are those developed by Grandjean $(1928,1974)$ (cf. Travé and Vachon 1975), those used by Norton and Behan-Pelletier (2009), as well as by Fernandez et al. (2011). Specific morphological characters have never before been described in detail, and hence no terminology or abbreviations exist. For the sake of clarity we have included the following in the text and on the figures:

cau cauliflower-like microtubercules;

s.c.f semicircular furrow.

\section{INSTITUTIONS}

MHNG Museum d'Histoire naturelle, Geneva;

MNHN Muséum national d'Histoire naturelle, Paris; NMP Natal Museum, Pietermaritzburg;

\section{SYSTEMATICS}

\author{
Family Plasmobatidae Grandjean, 1961 \\ Genus Solenozetes Grandjean, 1932
}

TYPe SPECIES. — Plasmobates cribratus Grandjean, 1929.

DiagNOSIS. - Prodorsal incision rounded at posterior end; microsculpture on notogastral cuticle irregular foveate pattern; notogaster without tuft of laciniures; anterior zone with prominent semicircular furrow; macropores opening inside foveae; opisthosomal gland apophysis not flat, extending forward; opening of podocephalic canal a simple pore; sejugal apodeme present; sejugal furrow deep; six pairs of genital setae; no aggenital setae; scalps without laciniures and without anterior indentation; larval scalp with three gibbose areas separated by transverse furrows.

\section{Solenozetes makokouensis n. sp.}

HolOTYPE. - Makokou, northeastern province of Ogoové-Ivindo, $500 \mathrm{~m}$. alt., dense evergreen humid forest, I.1974, Y. Coineau, 1 ○ (MNHN-Ac1165).

PARATYPES. - Same data as holotype, 9 9 ( 3 in MNHN, MNHN-Ac1 166; 3 in MNHG; and 3 in NMP). All specimens are preserved in $70 \%$ ethanol.

TYPE LOCALITY. - Makokou, province of Ogoové-Ivindo, northeastern Gabon; situated at 0³4'0”N, 1252'0”E.

ETymology. — Named after type locality.

Diagnosis (adult Female). - Characterised by the following combination of character states: cerotegument, amorphous layer: prodorsum, genital plate, surrounding anal opening; slightly tuberculate layer: internal bothridia; mixed layer: infracapitulum, epimeres, lateral body; ro seta simple, inflated in middle zone, inserted on protuberance with forward extending basal visor; in seta inserted on large protuberance; only apical part of seta visible; in seta wrapped in cerotegumental granulate layer; prodorsal anterior zone covered with complex irregular protuberances; incision narrow, rounded posteriorly; bothridium horseshoe-shaped; internal bothridial rings gear-like; sensillus filiform; semicircular anterior notogastral furrow and depressed zone; macropores opening on foveae. Microsculpture behind depressed zone irregularly foveate; opisthosomal gland apophysis conical, rounded tip; sejugal apodeme present; sejugal furrow deep; aggenital setae absent; simple pore opening podocephalic canal; notogastral setae five pairs; genital setae six pairs; setae $d$ on tibia I small, associated with $\varphi_{1}$; larval scalp with three gibbose areas separated by 
transverse furrows; two anterior, rounded; posterior, large extended irregular multi-gibbous dorsal surface, tritonymphal scalps not incised.

\section{REMARK}

In several of our samples we found males of very different size; at this moment we work with new samples, to understand the situation.

\section{ADULT DESCRIPTION}

\section{Measurements}

Total length $250 \mu \mathrm{m}(232-279 \mu \mathrm{m})$; notogastral width $133 \mu \mathrm{m}(111-157 \mu \mathrm{m})$ (light microscopy measurements). Total length $233 \mu \mathrm{m}(221-247 \mu \mathrm{m})$; notogastral width $152 \mu \mathrm{m}(150-183 \mu \mathrm{m})(\mathrm{SEM}$ measurements).

Shape: specimens with scalps ovoid in dorsal view (Fig. 1A), medial superior zone irregularly gibbous (larval scalps); in lateral view pyramidal (Fig. 6A). Specimens without scalps (Figs 3B; 5A, B, C, E): prodorsum flat to slightly globose; posterior zone of notogaster globular; anterior zone with well defined furrow.

Colour: specimens without cerotegument and scalps, dark yellow to medium brown.

\section{Cerotegument (scalps not considered)}

Thick complex layer, composed of wax layer and amorphous cement layer (Norton et al. 1997); present over entire body and legs, with elaborate patterns and structures in four different layer types: amorphous; small tuberculate, mixed and granulate (see below).

Amorphous layer: prodorsum, bothridial external zone, seta in on tubercle (Figs 2A; 4B, C), genital plate and surrounding zone, anal plate and surrounding zone.

Small tuberculate layer: internal bothridial zone (Fig. 4C, E).

Mixed layer: constituted by mushroom-like microtubercles (mus) associated with cauliflower-like microtubercles (cau) (Fig. 2B, D, G); mus diameter 0.1-0.9 $\mu \mathrm{m}$, height 0.5-2.0 $\mu \mathrm{m}$; cau diameter 0.9$3.1 \mu \mathrm{m}$, height 1.5-2.9 $\mu \mathrm{m}$. Distribution: infracapitulum, epimeric zone, lateral body zone.

Granulate layer: wrapping interlamellar setae, only small sections of setae visible (Fig. 4B, D).
Legs covered by amorphous layer, with prominent folds.

\section{Integument}

Prodorsum, tuberculate microsculpture (Fig. 3B): particularly in medial zone; the attachment in zone of the exuvial medial band extension (m.b) is attached, tubercles small and only discernible in lateral inclined view, in dorsal view zone smooth (Fig. 3D); anterior zone, tubercles small.

Notogaster, dorsal posterior zone tuberculate (Figs 3B; 5A, C); smooth towards bng (Fig. 5E); laterally with ridges separated by furrows (Fig. $5 \mathrm{E}$ ). Anterior depressed zone situated backwards toward macropores with many parallel ridges separated by furrows (Fig. 5A, C), terminating in front of macropores, clearly visible in inclined lateral view. Zone behind depressed area, irregularly foveate patterns, variable lengths, distributed around central zone (Fig. 3B).

Macropores $(m p)$, varying in size (diameter 0.5$1.2 \mu \mathrm{m})$, openings situated in small depressed circular zones; circumgastric distribution; anterior zone in single line near $d s j$; middle posterior zone, numerous macropores irregularly distributed (Fig. 5A, C, E); internal channel clearly visible close to cuticle.

Ventral, tuberculate (Fig. 3A); tubercules of epimeric zone small; posterior zone around genital and anal openings, large tubercles. Genital and anal plates, slightly rugose to smooth.

\section{Setation}

Lamellar, notogastral, subcapitular, exostigmatal, epimeric, genital and anal setae spiniform; rostral seta simple, inflated in middle zone (Fig. 3C) (13$15 \mu \mathrm{m}$ ); interlamellar setae (10-12 $\mu \mathrm{m})$, (Fig. 4B, D) filiform.

\section{Prodorsum}

Specimens with scalps (Figs 1A, B, C, D); medial band extension $(m . b)$ on central part up to rostrum. Medial zone around area covered by medial band extension, elevated (Fig. 1B, C), latter area easily discernible (Fig. 3D). Near $d s j$ and medial posterior part, flat to slightly gibbose (Fig. 5B), microtuberculate. 

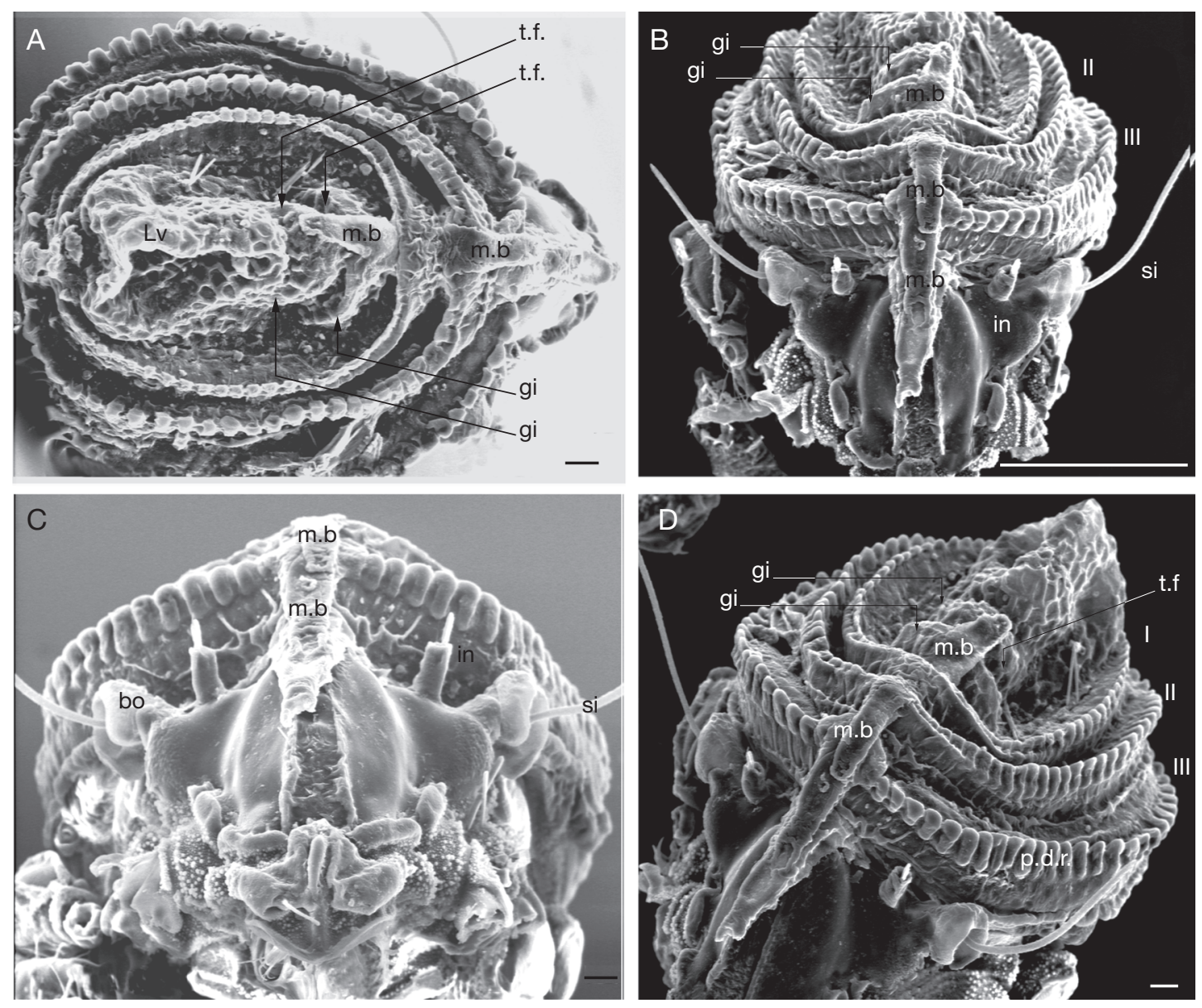

FIG. 1. - Solenozetes makokouensis n. sp., adult, SEM, with scalps and cerotegument: A, dorsal view; B, frontal view; C, prodorsum; D, lateral inclined view. Abbreviations: bo, bothridium; gi, gibose area; I,II,III,nymphal scalps; in, interlamellar setae; Lv, larval scalp; m.b, medial band extension; p.d.r, dentate peripheral ridge; si, sensillus; t.f, transverse furrow. Scale bars: A, C, D, $10 \mu \mathrm{m} ; \mathrm{B}, 100 \mu \mathrm{m}$.

Interlamellar seta (in), inserted near bothridial base on large protuberance, extending upwards (Figs 1B, $\mathrm{C}, \mathrm{D} ; 4 \mathrm{~B}, \mathrm{D})$; lamellar seta (le) small, inserted on small protuberance; rostral seta ( $r o$ ) inserted on basal zone of protuberance with forward-extending visor present (Fig. 3C).

Anterior zone of rostrum complex in structure; zone behind and around insertion of rostral seta with many irregular protuberances (Fig. 5B). Rostrum medially incised (Fig. 3D). Incision narrow, terminating in tooth-like projection; in frontal view the tooth is less pronounced and appears rounded; in dorsal view (Fig. 3B) posterior incision end rounded.
Bothridium (Fig. 1C) prominent, opening directed sideways (Fig. 4C), horseshoe-shaped; bothridial rim dorsally semicircular, basally incised, with thin rectilinear wall running across incision $(r . w)$. Internal bothridial rings gear-like (Fig. 4C, E).

Sensillus filiform $(86-112 \mu \mathrm{m})$, minutely barbed (Figs 5B; 6A, B, D); diameter of pedicel 0.6-1 $\mu \mathrm{m}$; exostigmatal seta (ex) small (Fig. 5B).

\section{Notogaster}

Near $d s j$, aligned macropores $(m p)$, opening inside foveae; $m p$ varying in size (diameter 0.4-0.8); internal channel close to cuticle. Distribution: circumgastric 

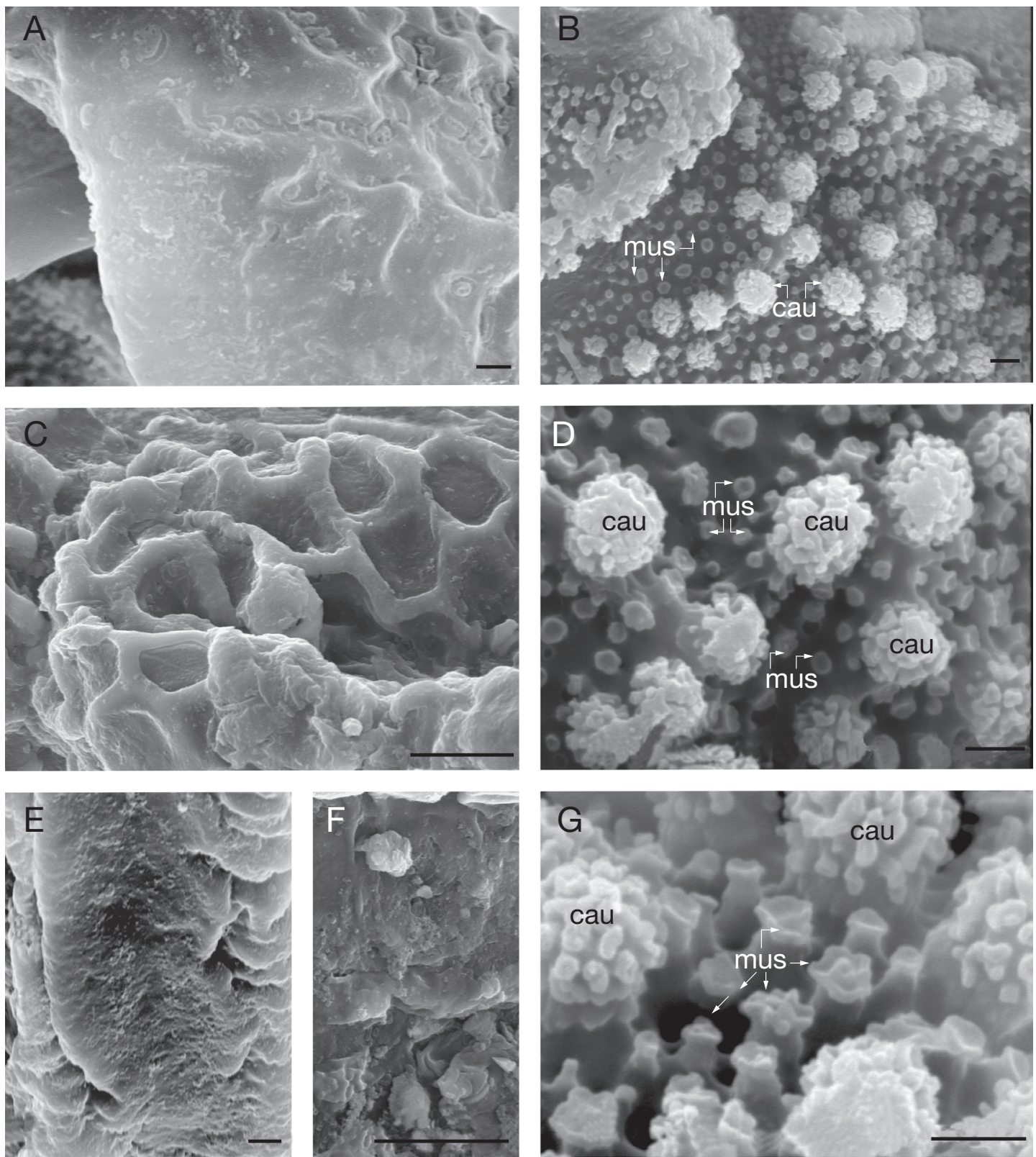

FIG. 2. - Solenozetes makokouensis n. sp., adult, SEM, cerotegument: A, bothridial external surface; B, epimeric region; C, scalp dorsally; D, mushroom-like and cauliflower-like microtubercles; E, medial band extension; F, detail of median band extension; G, detail of mushroom-like and cauliflower-like microtubercles. Abbreviations: cau, cauliflower-like microtubercles; mus, mushroom-like microtubercles. Scale bars: A, B, D, E, G, $1 \mu \mathrm{m} ; \mathrm{C}, \mathrm{F}, 10 \mu \mathrm{m}$.

(Fig. 3B); anteriorly in a simple ring; in front of and behind the opisthosomal gland several alignments and numerous pores (Fig. 5A, C, E).
The anterior zone, near $d s j$, and posterior to macropores a well defined semicircular furrow (s.c.f), clearly visible in inclined lateral view (Fig. 5C); 


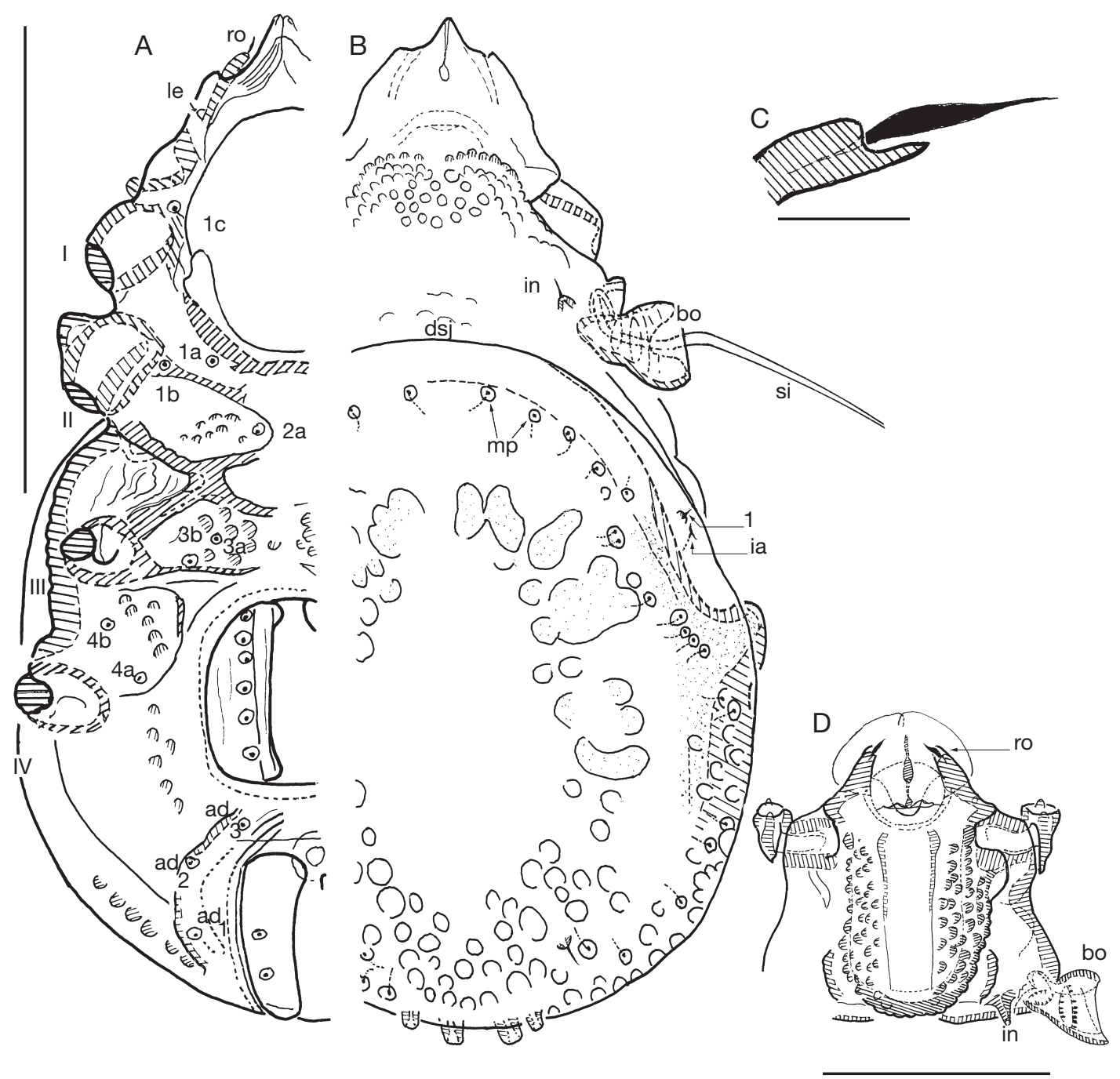

FIG. 3. - Solenozetes makokouensis n. sp., adult: A, ventral view, B; dorsal view, C; seta ro; D, prodorsum, dorsal view. Abbreviations: 1a-c, 2a, 3a, 3b, 4a ,4b, epimeric setae; ad1-3, adanal setae; dsj, dorsosejugal furrow; I,II,III,IV, acetabula; ia, lyrifissure; in, interlamelar setae; le, lamelar setae; ro, rostral setae; mp,macropore; 1, notogastral setae; bo, bothridium; si, sensillus. Scale bars: A, B, C, E, $100 \mu \mathrm{m} ; \mathrm{D}, 10 \mu \mathrm{m}$.

s.c.f extending to a third of anterior notogaster and delimiting a prominent depressed zone crossed by many more or less parallel ridges, separated by furrows (Fig. 5A, C).

Apophysis of opisthosomal gland (apo.gla) (opisthonotal gland sensu Norton and Behan-Pelletier 2009) conical, round tipped, positioned laterally (Figs 3B; 5A, E) extending forward.
Five pairs of notogastral setae, one anterior and four posterior; intraspecific setae variability between five to six pairs, last additional pair small, dorsally to seta 5 , situated in macropore zone. Five pairs of lyrifissures (ia, im, ih, ips, ip) (Fig. 5A, E).

\section{Ventral region}

Specimens with cerotegument: epimeral furrows easily discernible, with mushroom-like microtubercules 

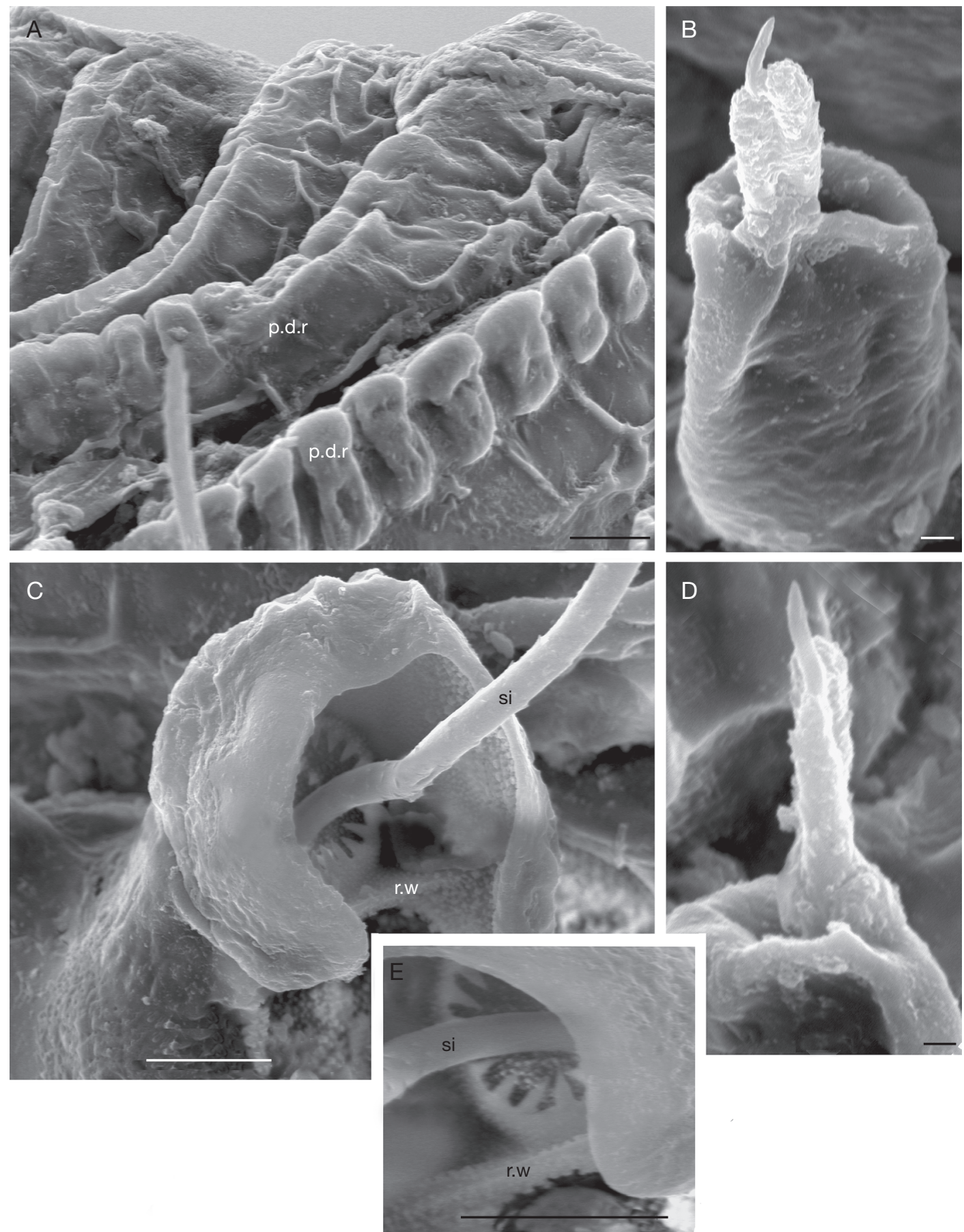

FIG. 4. - Solenozetes makokouensis n. sp., adult, SEM, with scalps and cerotegument: A, notogaster, anterior part; B, seta in, laterally; C, bothridium; D, seta in, frontal view; E, bothridium, internal bothridial detail. Abbreviations: p.d.r, dentate peripheral ridge; r.w, rectilinear wall running across incision; si, sensillus. Scale bars: A, C, E, $10 \mu \mathrm{m}$; B, D, $1 \mu \mathrm{m}$. 


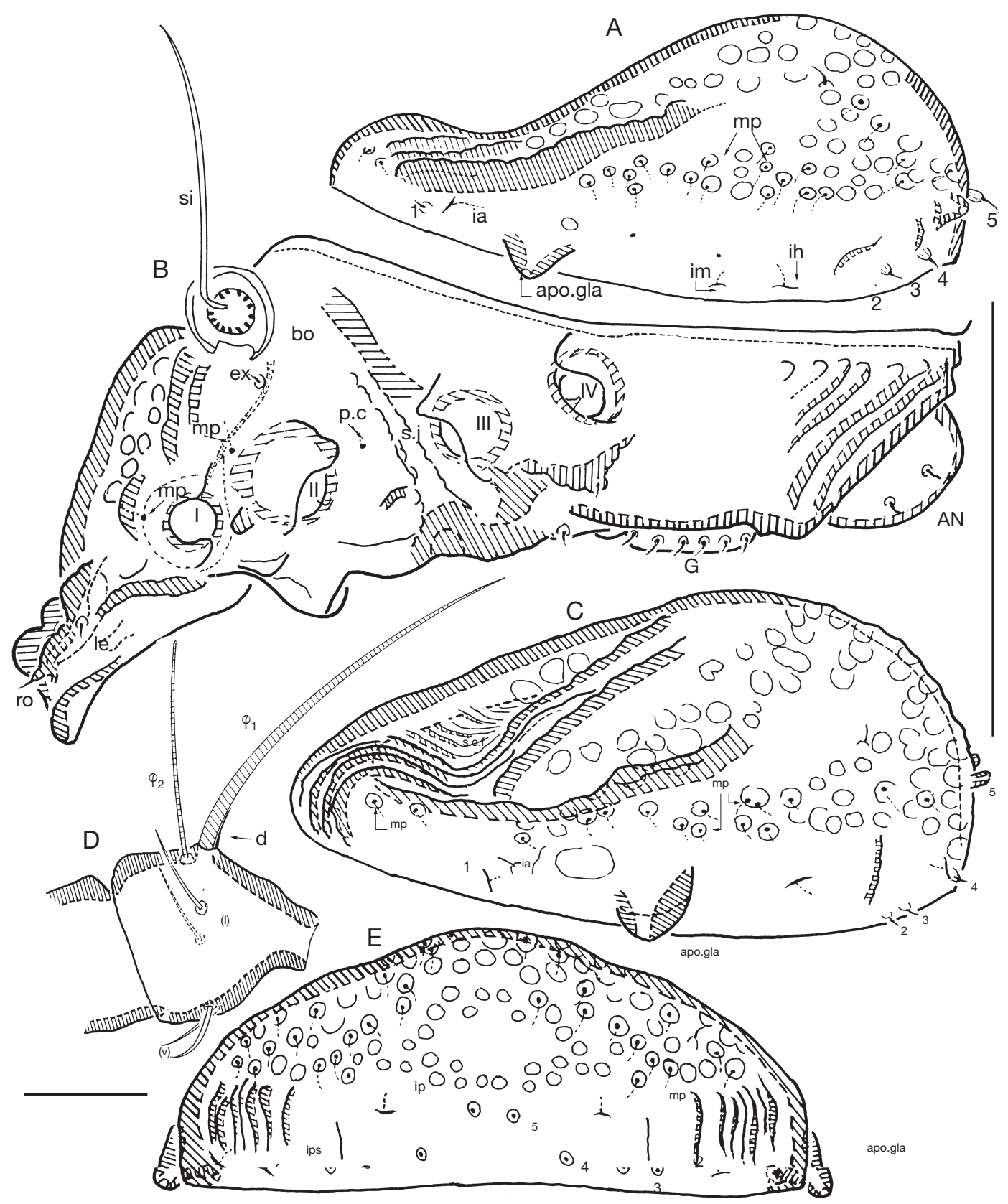

FIG. 5. - Solenozetes makokouensis n. sp., adult: A, notogaster, lateral view; B, general lateral view, without notogaster (setae in, not visible in this position, hidden by bothridium); C, notogaster lateral view, slightly inclined to ventral and rotated to rear; D, tibia I; E, notogaster, posterior view. Abbreviations: 1-5, notogastral setae; AN, anal plate; apo.gla, apophysis opisthosomal gland; bo, bothridium; (I),(v), tibial setae; ex, exostigmatal setae; G, genital plate; I,II,III,IV, acetabula; ia, im, ih, ip, ips, lyrifissures; le, lamelar setae; mp, macropore; p.c, simple pore; ro, rostral setae; s.c.f, semi circular furrow; si, sensillus; sj, sejugal furrow; $\varphi \mathbf{1}, \varphi 2$, solenidia. Scale bars: A, B, C, E, $100 \mu \mathrm{m} ; \mathrm{D}, 10 \mu \mathrm{m}$. 
(mus) and cauliflower-like microtubercules (cau) (Fig. 2B, D, G). Specimens without cerotegument (Fig. 3A): cuticle smooth. Epimeral furrows very flat, only bo.sj. deeper; in medial epimeric zone depression more or less triangular in shape. Apodemes I and II close to each other; sj thin; III small, divided; IV less defined. Epimeral setal formula (3-1-2-2) (Fig. 3A). Genital setation six pairs, in a single longitudinal row; aggenital seta absent; adanal setae three pairs; anal setae two pairs; lyrifissure (ian) not visible.

\section{Lateral region}

Exobothridial seta (ex) small but clearly discernible (Fig. 5B); two macropores: one below ex; another opening in front of leg I (Fig. 5B, indicated with $m p$ and arrow). Opening of podocephalic canal only discernible as simple pore (p.c) (Fig. 5B). Tubercle of interlamellar seta more or less cylindrical, depressed in apical central zone around setae insertion (Fig. 4B, D).

Seta ro inserted on prominent tubercle (Fig. 3C). Rostral tubercle with forward extending anterior ventral visor (Fig. 3C). Behind tubercle of rostral seta and extending behind seta le a well defined zone of many elevated, more or less aligned cuticular thickenings (Fig. 5B). Rostral margins smooth, cuticle more or less hyaline (Fig. 3D).

Sejugal depression deep, easily discernible (Fig. 5B). Behind acetabulum III and below the level of acetabulum IV, a prominent cuticular thickening. Between anal opening and level of genital opening, many cuticular thickenings equidistantly aligned (Fig. 5B). Lyrifissures $i a$, im, ih, ip, ips, clearly visible (Fig. 5A, C). Notogastral setae on small protuberances (Fig. 5A, C).

\section{Gnathosoma}

Subcapitulum suctorial with short tube. Subcapitular setae large. Chelicerae without setae (Fig. 6C); Trägårdh’s organ large.

\section{Legs}

Setal and solenidial formulae (trochanter to tarsus): I (1-5-5-5-20-1) (1-2-2); II (1-5-4-4-14-1) (1-1-2); III (2-3-2-4-13-1) (1-1-0); IV (1-3-2-4-13-1) (0-1-0).

\section{Scalps}

Exuviae of immature stases adhering one on top of the other, creating a multilayered structure; anteriorly each scalp extends in a medial band (m.b) (Fig. 1A, $\mathrm{B}, \mathrm{C}, \mathrm{D})$. Medial band covering the central zone, firmly adhering on prodorsal surface (Fig. 1C) and extending to the rostrum. Scalps (medial band included) firmly attached. Cerotegumental layer: medial band covered by thick amorphous layer (Fig. 2E, F); rest of scalp covered by layer with network of round to polygonal depressions patterns (Fig. 2C). Shape of larval scalp different from that of other stases, broad and elevated, with three gibbose areas $(g i)$ separated by transverse furrows $(t . f)$ (Fig. 1A, D); the anterior two rounded and more or less similar in shape and length; posterior one large, extended with irregular multi-gibbous dorsal surface (Fig. 1A, D). In lateral view shaped like a chinese hat (Fig. 6A).

Nymphal scalps with dentate peripheral ridge (p.d.r) (Figs 1A-D; 4A; 6A, B). Setae hardly discernible. Scalps simple without anterior tuft of filaments and without anterior indentation.

\section{REMARKS}

Legs chaetotaxy, the only difference between $S$. makokouensis and Malgachebates peyrierasi is seta $d$ associated with solenidion $\varphi_{1}$ on tibia I very small and attached to solenidion.

\section{DISCUSSION}

Against the background of the paper of Hunt (1994) and its text references to the work of Grandjean (1929, 1932, 1961a), we deemed it necessary to transcribe some paragraphs for the purpose of analysis and clarity.

First of all we need to point out that Hunt (1994) produced an extremely interesting and valuable work based on SEM studies only.

1) on page 129 , discussing characteristics on generic level, he stated: "Scalps. Grandjean (1932) erected Solenozetes as he considered the type species, Plasmobates cribratus Grandjean, 1929 from Venezuela, possessed only a tritonymphal scalp. In his 1961 paper, however, he regarded this as an er- 

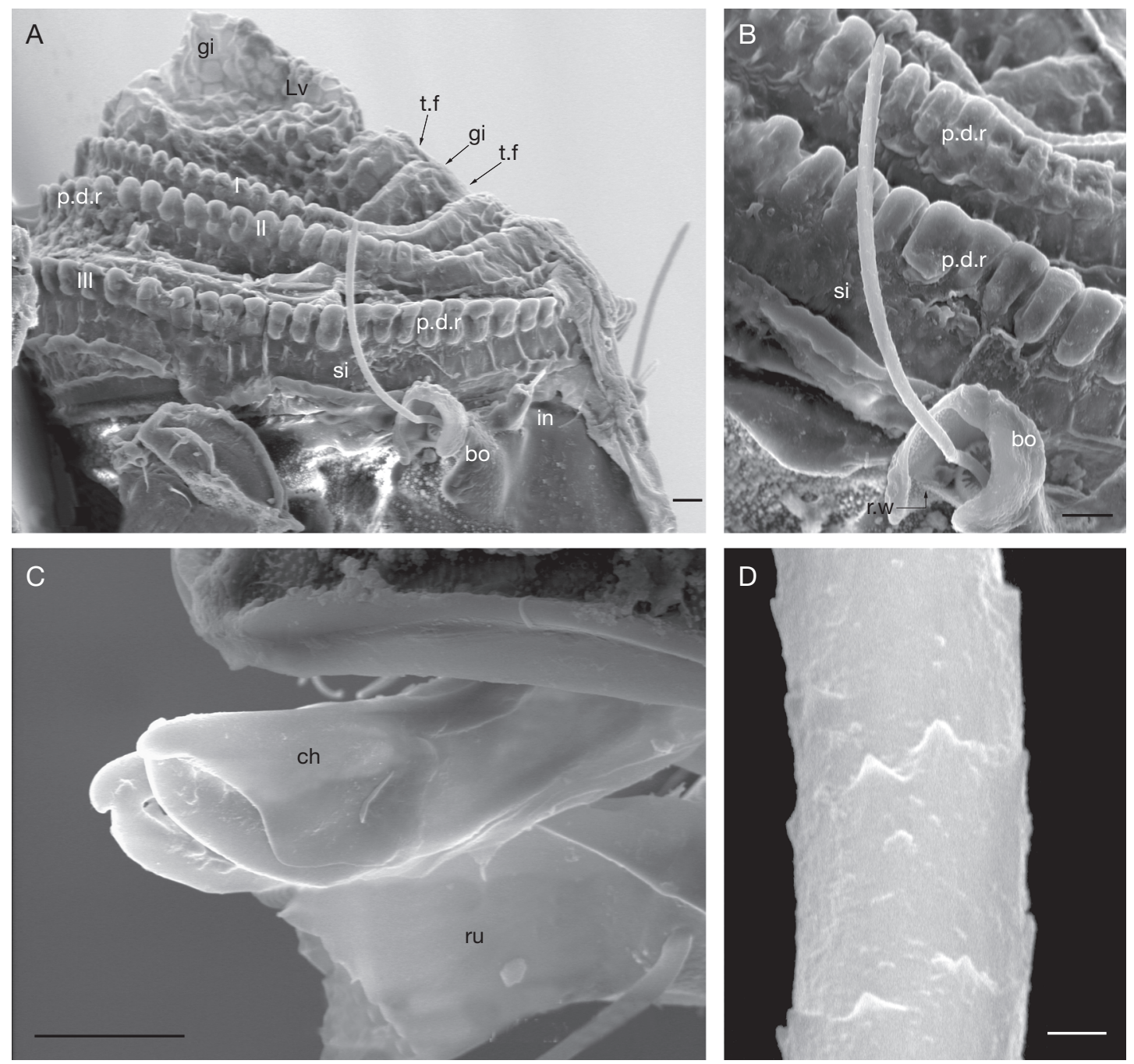

FIG. 6. - Solenozetes makokouensis n. sp., adult, SEM: A, lateral view; B, Detail of bothridium and crest of scalps; C, chelicera; D, detail, sensillus. Abbreviations: bo, bothridium; gi, gibose areas; I,II,III, nymphal scalps; in, interlamelar setae; Lv, larval scalp; p.d.r, dentate peripheral ridge; si, sensillus; t.f , transverse furrows. Scale bars: A, B, C, $10 \mu \mathrm{m} ; \mathrm{D}, 1 \mu \mathrm{m}$.

ror (scalps can fall off) and questioned the separate status of Solenozetes. He nevertheless retained the genus, without giving a clear rediagnosis".

2) With reference to the shape of the bothridium, Hunt (1994) page 131 also stated: "Shape of bothridium. Except perhaps for Orbiculobates transvectus (Grandjean, 1929) descriptions of species with six pairs of genital setae (and Plasmobates javensis) seem to indicate that the bothridial wall forms a partial hood over the bothridial cavity but is deeply invaginate anterolaterally (Fig. 1C). In Plasmobates pagoda and Plasmobates asiaticus (seven pairs), the bothridium is not hooded and has a much more open structure. It is invaginate in the mesad [probably medial zone] as well as the lateral wall. A "hooded" bothridium may be a shared de- 
rived character for Solenozetes and Oribiculobates, as suggested by its absence in Hermaniellidae and Liodidae, outgroups which have a low, open bothridium. The more open bothridium seems to be correlated with a shorter sensillus."

With reference to point 1) of Hunt's paper (1994), it should be pointed out that he did not take into consideration the information pointed out by Grandjean (1961a) on page 123: "Je n'ai rien observé de nouveau pour cribratus car l'unique exemplaire a disparu. Je ne l'ai pas retrouvé dans le tube d'acide lactique où je l'avais mis après mon ancienne étude. Sa description est incomplète mais il suffira vraisemblablement à reconnaître l'espèce. Il faudra la compléter pour savoir au juste ce que signifie le genre Solenozetes" and in the same paper Grandjean indicated on page 127: "Solenozetes Grandj. 1932. La seule espèce, décrite autrefois comme Plasmobates, S. cribratus (Grandj. 1929) est trop incomplètement décrite pour qu'il soit possible de donner du Solenozetes une diagnose". Finally, Grandjean stated (1961a, page 123): "Une meilleure connaissance des Plasmobatidés permet en outre d'affirmer contrairement à ce que j'ai dit en 1932 (8, p. 653), que cribratus est un Euphéréderme comme pagoda, porteur des 4 scalps à la stase adulte. L'unique exemplaire n'avait sans doute perdu que les scalps de la larve, de la proto et de la deutonymphe".

It is also necessary to point out that the citation “Grandjean 1932 (8, p. 653)" in Grandjean 1961a, is erroneous, the citation should be numbered three and not eight.

In the above transcribed text, Grandjean (1961a) indicated: a) the impossibility to give a rediagnosis due to the loss of the type material; b) that cribratus is an eupheredermous where the adult stage carries four scalps, similar to pagoda; and c) that he did not doubt that his only specimen of cribratus lost the larval, protonymphal and deutonymphal scalps. For the reasons explained above, it was impossible for Grandjean to give a complete description of the single species existing in the genus Solenozetes at that time.

With reference to scalps and the related structures Grandjean (1961a) indicated, in the redefinition of the genera Plasmobates and Orbiculobates (pages 126-127) "Plasmobates GRANDJ. 1929.-. Scalps sans échancrure en avant. Scalp larvaire à 3 fortes dépressions transversales" and "Orbiculobates n. g. -Scalp tritonymphal échancré au-dessus de la touffe de laciniures. Scalp larvaire à une seule dépression transversale profonde". Evidently he was not able to study the scalps of $S$. cribratus to add to the description for diagnosing the genus Solenozetes (Grandjean 1961a: 127).

Hunt (1994) considered that scalp morphology appears to be useful only at species level; however we consider these two characteristics (see Redefinition-Diagnosis): (a) presence-absence of total or partial anterior indentation of scalps above tuft of filaments, and (b) number of transversal depressions on larval scalps, to be useful at generic level; the other characteristics (dentate peripheral ridge, medial band, setae, etc) are probably characters that can be applied at species level.

With reference to point 2) (cited above), we wish to point out that several publications exist which clearly indicate that the bothridium and the sensilli are remarkable structures that are both of great taxomomic importance (Alberti et al. 1994; Evans et al. 1961; Grandjean 1961b; Tarman 1961; Krantz 1978; Van der Hammen 1989; Woolley 1988), thus it is imperative always to interpret form and function based on structural studies (optical microscopy and SEM), ultrastructural studies (TEM), and physiological studies. The bothridial organs are regarded as vibro- and anemoreceptors (Van der Hammen 1980), with a distinct cuticular structure developed around the base of a specialised seta (Alberti et al 1994). The sensillus is a sensorial seta inserted into a deep cup-like socket (Reißland \& Görner 1985; Van der Hammen 1980). Besides a meager number of SEM photos and schematic drawings in species descriptions, actual knowledge about this significant and complex organ in the Plasmobatidae is very limited, and it is necessary to await new insights and understanding in order to infer possible relations.

It is necessary to point out that we could not trace any references on bothridial organs with similar external aspects as those found in Solenozetes makokuensis and Malgachebates peyrierasi, such as having an external horseshoe-shaped bothridium, which 
is basally incised, with gear-like internal bothridial rings, and with the sensillus diameter changing between downward-sloping and upward-sloping bothridial rings.

Relating the shape of the bothridium and sensillus, as well as the presence of six or seven pairs of genital setae, based on a small number of species and without the necessary ultrastructural and physiological studies seems a little risky.

\section{CONCLUSION}

The situation with reference to Plasmobatidae is extremely complicated, due to the existence of many brief and imprecise descriptions not supported by detailed figures (in many cases only a drawing of the dorsal aspect). Both optical microscopy and SEM studies need to be applied due to their complementary nature.

It is just not possible to define species based on one or two characters obtained from only a single specimen without considering possible intraspecific variability. Important characters such as cerotegument, prodorsal incision, macropores, apodemes, epimeres, genital plates, anal plates, aggenital and adanal areas, opening of podocephalic canal, scalps, legs (segment articulations, setal formulae, position and shape of solenidions, etc.) have been neglected.

Evidently the following characteristics: dorsal infracapitulum, chelicerae, palps, rutella and tracheal systems are very important, but to obtain such information it is necessary to work with dissected specimens. However, many descriptions contain only a few lines of rapidly completed descriptions of the dorsal aspect without any reference to ventral and lateral aspects.

Finally, we consider descriptions of $S$. flagellatus Balogh \& Mahunka, 1969 and S. australis Balogh \& Csiszár, 1963 to be very deficient, making it impossible to recognise these species and they should thus be considered species inquirendae.

\section{Acknowledgements}

I am grateful to Regis Cleva for her friendly collaboration and highly efficient in the SEM studies.
This work is based partly upon research supported by the National Research Foundation (NRF), South Africa. Any opinion, findings and conclusions or recommendations expressed in the material are those of the authors and therefore the NRF does not accept any liability in regard thereto.

\section{REFERENCES}

Alberti G., Moreno A. \& KratzMann M. 1994. The fine structure of trichobothria in moss mites with special emphasis in Acrogalumna longipluma (Berlese, 1904) (Oribatida, Acari, Arachnida). Acta Zoologica 75 (1):57-74.

Evans G.o., Sheals J.g. \& MaCFalane D. 1961. — The Terrestrial Acari of the British Isles. An introduction to their morphology, biology and classification. Vol. 1. Introduction and Biology London British Museum (Natural History), $219 \mathrm{p}$.

Fernandez N., Cleva R. \& Theron P. 2011. - Malgachebates peyrierasi n. gen. n. sp. (Acari, Oribatida, Plasmobatidae) from Madagascar. International Journal of Acarology 37 (1): 61-74

GRANDJEAN F. 1928. - Sur un Oribatidé pourvu d'yeux. Bulletin. Société. Zoologique de France, 53: 235-242, figs 1-4.

GRANDJEAN F. 1929. - Quelques nouveaux genres d'oribatei du Venezuela et de la Martinique. Bulletin de la Société Zoologique de France 54: 400-423.

GRANDJEAN F. 1932 - Observations sur les Oribates (2e série). Bulletin du Muséum national d'Histoire naturelle Paris 3:651-665.

GRANDJEAN F. 1949. - Observation et conservation des très petits arthropodes. Bulletin du Muséum National d'Histoire Naturelle, Paris, 21: 363-370.

GRANDJEAN F. 1961a. - Les Plasmobatidae n. fam. (Oribates). Acarologia 3: 96-129.

GRANDJEAN F. 1961b. - Nouvelles observations sur les Oribates (1 re série). Acarologia 3: 206-231.

GRANDJEAN F. 1974. - Caractères anormaux et vertitionnels rencontrés dans les clones de Platynothrus peltifer (Koch) - Chapitre VII à XIII de la deuxième partie. Acarologia 15: 759-780.

HUNT G. S. 1994. - Solenozetes gallonae sp. nov., first record of the Plasmobatidae in Australia (Acari:Oribatida). Memoirs Queensland Museum 35 (1):129-134.

Krantz G.W. 1978. - A manual of Acarology, Oregon State University Book Stores, Inc.Corvalis, 509 p.

Krantz G.W. \& Walter D.E. 2009. - A Manual of Acarology. $3^{\text {rd }}$ ed. Texas Tech University Press, Lubbock, TX, 807 p.

Norton R. \& Behan-Pelletier V. 2009. — Suborder Oribatida. In: Krantz, G. W. and D. E. Walter (Eds.). A Manual of Acarology. 3rd ed. Texas Tech 
University Press, Lubbock, Texas: 430-564.

Norton R., Alberti G., WeIgmann G. \& WoAs S.T. 1997. - Overview of types and distributions. In: ALBERTI, G. and R. NORTON (Eds.). Porose Integumental Organs of Oribatid Mites (Acari, Oribatida). Zoologica 146: 1-31.

REIßLAND A. \& GÖRNER P. 1985. — Trichobothria. In

F. G. Barth (Ed). Neurobiology of arachnids Springer, Berlin: 138-161.

SUBIAS L. 2004. — Listado sistemático, sinonímico y biogeográfico de los Ácaros Oribatidos (Acariformes: Oribatida) del Mundo (excepto fósiles). Graellsia 60: 3-305 (Updated April 2012, http://www.ucm.es/info/ zoo/Artropodos/Catalogo.pdf).

TARMAN K. 1961. - Über Trichobothrien und Augen bei Oribatei. Zoologischer Anzeiger 167: 51-58.
Travé J. \& VaChON M. 1975. — François Grandjean 1882-1975 (Notice biographique et bibliographique). Acarologia 17 (1): 1-19.

VAN DER HAMMEN L. 1980. — Glossary of acarological terminology Vol. 1. General terminology. The Hague. W. Junk, 244 p.

Van Der Hammen L. 1989. - An introduction to comparative arachnology. SPB Academic Publishing. The Hague, 576 p.

UNESCO 1987. - Makokou, Gabon: a research station in tropical forest ecology; overview and publications, 1962-1986 (IRET (Gabon); CNRS (France). UNESCO-MAB), $52 \mathrm{p}$.

WoOlLEY T. A. 1988. - Acarology: Mites and Human welfare, John WILEY, New York, 484 p.

Submitted on 25 June 2012; accepted on 5 September 2012; published on 28 June 2013. 